\title{
Multiplex Real-Time PCR Assay for Six Major Carbapenemase Genes
}

\author{
Nori Yoshioka ${ }^{1,2, *(\mathbb{D})}$, Hideharu Hagiya ${ }^{1,3}$ (D) Matsuo Deguchi ${ }^{1,2}$, Shigeto Hamaguchi ${ }^{1}$, Masanori Kagita ${ }^{1,2}$, \\ Isao Nishi ${ }^{1,2}$, Yukihiro Akeda ${ }^{1}$ and Kazunori Tomono ${ }^{1}$ \\ 1 Division of Infection Control and Prevention, Osaka University Hospital, 2-15 Yamadaoka, Suita, \\ Osaka 565-0871, Japan; hagiya@okayama-u.ac.jp (H.H.); exit@hp-lab.med.osaka-u.ac.jp (M.D.); \\ hamaguchi@hp-infect.med.osaka-u.ac.jp (S.H.); kagita@hp-lab.med.osaka-u.ac.jp (M.K.); \\ nishi@hp-lab.med.osaka-u.ac.jp (I.N.); akeda@biken.osaka-u.ac.jp (Y.A.); \\ tomono@hp-infect.med.osaka-u.ac.jp (K.T.) \\ 2 Laboratory for Clinical Investigation, Osaka University Hospital, 2-15 Yamadaoka, Suita, \\ Osaka 565-0871, Japan \\ 3 Department of General Medicine, Okayama University Graduate School of Medicine, Dentistry and \\ Pharmaceutical Sciences, 2-5-1 Kitaku Shikatachou, Okayama 700-8558, Japan \\ * Correspondence: yoshioka@hp-infect.med.osaka-u.ac.jp; Tel.: +81-6-6879-3852
}

check for updates

Citation: Yoshioka, N.; Hagiya, H.; Deguchi, M.; Hamaguchi, S.; Kagita, M.; Nishi, I.; Akeda, Y.; Tomono, K. Multiplex Real-Time PCR Assay for Six Major Carbapenemase Genes. Pathogens 2021, 10, 276. https:// doi.org/10.3390/pathogens10030276

Academic Editor: Pratik Banerjee

Received: 20 December 2020

Accepted: 26 February 2021

Published: 1 March 2021

Publisher's Note: MDPI stays neutral with regard to jurisdictional claims in published maps and institutional affiliations.

Copyright: (c) 2021 by the authors. Licensee MDPI, Basel, Switzerland. This article is an open access article distributed under the terms and conditions of the Creative Commons Attribution (CC BY) license (https:/ / creativecommons.org/licenses/by/ $4.0 /)$.

\begin{abstract}
The global dissemination of carbapenemase-producing Enterobacteriaceae (CPE) is a major concern in public health. Due to the existence of the diversity of carbapenemases, development of an easily available, cost-effective multiplex detection assay for CPE is required worldwide. Using clinically available and reliable equipment, $\operatorname{COBAS}^{\circledR} \mathrm{z} 480$ (Roche Diagnostics K.K., Tokyo, Japan), we developed a multiplex real-time PCR assay for the detection of two combinations of carbapenemases; first, $b l a_{\mathrm{NDM}}, b l a_{\mathrm{KPC}}$, and $b l a_{\mathrm{IMP}}$ (Set 1), and second, bla $a_{\mathrm{GES}}, b l a_{\mathrm{OXA}-48}$, and $b l a_{\mathrm{VIM}}$ (Set 2). We constructed standard curves for each carbapenemase gene using serial dilutions of DNA standards, then applied reference or clinical isolates with each carbapenemase gene to this assay. The multiplex assay showed satisfactory accuracy to detect CPE genes, with the correlation coefficients of greater than 0.99 for all genotypes. The assay appropriately differentiated the reference or clinical strains harboring each carbapenemase gene without cross reactivity. Lastly, the assay successfully detected multiple genes without false-positive reactions by applying six clinical isolates carrying both NDM and OXA-48-like carbapenemase genes. Major advantages of our assay include multiplicity, simple operation, robustness, and speed $(1 \mathrm{~h})$. We believe that the multiplex assay potentially contributes to early diagnosis of CPE with a diverse genetic background.
\end{abstract}

Keywords: carbapenem-resistant Enterobacteriaceae; carbapenemase-producing Enterobacteriaceae; infection control; multiplex detection assay

\section{Introduction}

The high antimicrobial resistance of carbapenemase-producing Enterobacteriaceae (CPE) is a significant threat to global public health [1,2]. Carbapenemases are classified into two groups; (i) metallo- $\beta$-lactamases (MBLs), such as NDM, VIM, and IMP, and (ii) serine- $\beta$ lactamases, such as KPC, OXA-48, and GES. Due to this genetic diversity, it is challenging to appropriately detect and differentiate CPE isolates at in-house laboratories.

To date, IMP-type CPE strains are predominantly found in Japan [3,4]; however, the risk of importing other CPE strains also increases with globalization. In this context, the development of a multiplex assay for several CPE strains is required to prevent and control the spread of infection. Several assays for the detection of CPE isolates have been developed [5-7], including immunochromatographic tests [8-10]. Here, we describe a novel multiplex assay to detect six major carbapenemase genes using previously developed single PCR primers and a clinically available COBAS ${ }^{\circledR}$ z480 (Roche Diagnostics K.K., Tokyo, Japan) equipment in a hospital setting. 


\section{Materials and Methods}

\subsection{Laboratory Examination}

\subsubsection{Bacterial Strains}

We then applied the following reference or clinical isolates of each carbapenemase gene to this assay: NDM, a clinical strain of bla $a_{\mathrm{NDM}-5}$-positive Klebsiella pneumoniae (accession numbers DRX117870 and DRX117871); KPC, an ATCC reference strain of K. pneumoniae BAA-1705 possessing bla $a_{\mathrm{KPC}-2}$ (accession number AOGQ00000000); IMP, a clinical strain of bla $a_{\mathrm{IMP}-6}$ positive K. pneumoniae (accession number DRX155515); GES, a clinical strain of bla $a_{\mathrm{GES}-24}$ positive K. pneumoniae (accession number DRA008464); OXA-48, a clinical strain of bla $a_{\mathrm{OXA}-232}$ positive K. pneumoniae (accession number DRX114774); and VIM, a clinical strain of bla $a_{\mathrm{VIM}-1}$ positive K. pneumoniae (accession number SAMEA2709037). We also applied six CPE clinical isolates that were confirmed to carry both NDM (bla $\left.a_{\mathrm{NDM}-1}\right)$ and

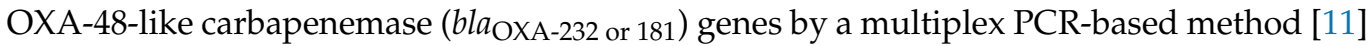
to confirm the utility of our assay to detect isolates harboring dual carbapenemase genes. We also applied 66 clinical isolates of Carbapenem Inactivation Method (CIM)-negative Enterobacteriaceae to evaluate the accuracy of the assay. The need for informed consent was waived because the study used only isolated pathogens and an individual's information was anonymized.

\subsubsection{Primers and Probes}

The details of primers and probes for NDM, KPC, IMP, GES, OXA, and VIM are shown in Table 1.

Table 1. Primers and probes used in the multiplex, quantitative, real-time PCR test.

\begin{tabular}{|c|c|c|c|c|}
\hline Gene & Primer Names & Probe & Sequences $\left(5^{\prime}-3^{\prime}\right)$ & Wavelength $(\mathrm{nm})$ \\
\hline NDM & $\begin{array}{c}\text { LightMix }^{\circledR} \\
\text { Modular NDM } \\
\text { Carbapenemase }\end{array}$ & $\begin{array}{l}\text { FAM labeled } \\
\text { hydrolysis probe }\end{array}$ & $\begin{array}{l}\text { F: GGTTTGGCGATCTGGTTTTC } \\
\text { R: CGGAATGGCTCATCACGATC }\end{array}$ & FAM (465-510) \\
\hline KPC & $\begin{array}{c}\text { LightMix }^{\circledR} \\
\text { Modular KPC } \\
\text { Carbapenemase }\end{array}$ & $\begin{array}{l}\text { LC610 labeled } \\
\text { hydrolysis probe }\end{array}$ & $\begin{array}{l}\text { F: ATGTCACTGTATCGCCGTCT } \\
\text { R: TTTTCAGAGCCTTACTGCCC }\end{array}$ & $610(540-610)$ \\
\hline IMP & $\begin{array}{c}\text { LightMix }^{\circledR} \\
\text { Modular IMP } \\
\text { Carbapenemase }\end{array}$ & $\begin{array}{l}\text { LC640 labeled } \\
\text { probe }\end{array}$ & $\begin{array}{l}\text { F: GAATAGRRTGGCTTAAYTCTC } \\
\text { R: CCAAACYACTASGTTATC }\end{array}$ & $640(610-645)$ \\
\hline GES & $\begin{array}{c}\text { LightMix }^{\circledR} \\
\text { Modular GES } \\
\text { Carbapenemase }\end{array}$ & $\begin{array}{l}\text { LC640 labeled } \\
\text { probe }\end{array}$ & $\begin{array}{l}\text { F: GCTTCATTCACGCACTATT } \\
\text { R: CGATGCTAGAAACCGCTC }\end{array}$ & $640(610-645)$ \\
\hline OXA & $\begin{array}{c}\text { LightMix }^{\circledR} \\
\text { Modular } \\
\text { OXA-48 } \\
\text { Carbapenemase }\end{array}$ & $\begin{array}{l}\text { R6G labeled } \\
\text { hydrolysis probe }\end{array}$ & $\begin{array}{l}\text { F: TTGGTGGCATCGATTATCGG } \\
\text { R: GAGCACTTCTTTTGTGATGGC }\end{array}$ & $580(540-580)$ \\
\hline VIM & $\begin{array}{c}\text { LightMix }^{\circledR} \\
\text { Modular VIM } \\
\text { Carbapenemase }\end{array}$ & $\begin{array}{l}\text { Cyan500 labeled } \\
\text { hydrolysis probe }\end{array}$ & $\begin{array}{l}\text { F: GTTTGGTCGCATATCGCAAC } \\
\text { R: AATGCGCAGCACCAGGATAG }\end{array}$ & FAM (465-510) \\
\hline
\end{tabular}

\subsubsection{PCR Conditions}

In the beginning, we intended to detect all six carbapenemase genes in a single assay; however, the equipment can process only up to four fluorescent dyes simultaneously. Therefore, we constructed two multiplex assays to detect two combination sets of three carbapenemase genes and an internal control; Set 1 and Set 2 consisted of $b l a_{\mathrm{NDM}}, b l a_{\mathrm{KPC}}$, and $b l a_{\mathrm{IMP}}$, and $b l a_{\mathrm{GES}}, b l a_{\mathrm{OXA}-48}$, and $b l a_{\mathrm{VIM}}$, respectively.

A $20-\mu \mathrm{L}$ reaction mixture consisting of $5 \mu \mathrm{L}$ sample DNA and $15 \mu \mathrm{L}$ master mix was used for this assay. For each sample, DNA was isolated by boiling bacterial suspension for $10 \mathrm{~min}$. For each reaction, the master mix contained $4 \mu \mathrm{L}$ LightCycler ${ }^{\circledR}$ Multiplex DNA Master; $0.5 \mu \mathrm{L}$ of each LightMix ${ }^{\circledR}$ Modular series primer and probe (TIB Molbiol $\mathrm{GmbH}$, Berlin, Germany; Table 1) and $0.5 \mu \mathrm{L}$ of LightMix ${ }^{\circledR}$ Modular PhHV internal control 
( $2 \mu \mathrm{L}$ in total) (TIB Molbiol GmbH, Berlin, Germany); $0.25 \mu \mathrm{L}$ LightCycler ${ }^{\circledR}$ Uracil-DNA Glycosylase (UNG) (Roche Diagnostics K.K., Tokyo, Japan); and $8.75 \mu \mathrm{L}$ PCR-grade water (Thermo Fisher Scientific Inc., Japan). The following wavelengths were used: Set 1: NDM, FAM (Excitation [Ex]. 465 nm; Emission [Em]. 510 nm); KPC, LC610 (Ex. 540 nm; Em. 610 nm); IMP, LC640 (Ex. 610 nm; Em. 645 nm); and PhHV, LC670 (Ex. 610 nm; Em. 670 nm). Set 2: GES, LC640 (Ex. 610 nm; Em. 645 nm); OXA, LC580 (Ex. 540 nm; Em. 580 nm); VIM, Cyan500 (Ex. 465 nm; Em. 510 nm); and PhHV, LC670 (Ex. 610 nm; Em. $670 \mathrm{~nm}$ ). Thermal cycling parameters were as follows: UNG activation at $40{ }^{\circ} \mathrm{C}$ for $10 \mathrm{~min}$ (1 cycle), Taq activation at $95^{\circ} \mathrm{C}$ for $10 \mathrm{~min}(1 \mathrm{cycle})$, followed by 45 cycles at $95{ }^{\circ} \mathrm{C}$ for $15 \mathrm{~s}, 60{ }^{\circ} \mathrm{C}$ for $30 \mathrm{~s}$, and $72{ }^{\circ} \mathrm{C}$ for $2 \mathrm{~s}$ (amplification), and $45^{\circ} \mathrm{C}$ for $30 \mathrm{~s}$ (cooling). The total duration of this assay is approximately $60 \mathrm{~min}$. We defined the detection limit as a concentration at which the coefficient of variation of the five replicates $(\mathrm{Log})$ per tube $(15 \mu \mathrm{L})$ is less than $10 \%$. Using this assay, we first used the DNA standards of $b l a_{\mathrm{NDM}}$, $b l a_{\mathrm{KPC}}, b l a_{\mathrm{OXA}-48}, b l a_{\mathrm{IMP}}, b l a_{\mathrm{VIM}}$, and $b l a_{\mathrm{GES}}\left(\mathrm{LightMix}{ }^{\circledR}\right.$ Modular series; TIB Molbiol GmbH, Berlin, Germany) to construct the standard curves. Four-fold serial dilutions $(8,40,200$, 1000 copies $/ 15 \mu \mathrm{L}$ ) of the positive controls were prepared and the experiments were performed in duplicate.

\subsubsection{Equipment}

In this study, we used the $\operatorname{COBAS}^{\circledR}$ z480 (Roche Diagnostics K.K., Tokyo, Japan) genetic analysis system.

\section{Results}

We constructed standard curves for the six carbapenemase genes using DNA standard solutions. As shown in Figure 1, the multiplex assays showed satisfactory accuracy for all genes. The correlation coefficients were greater than 0.99 for all genes. The lower limits of quantification were confirmed to be $\geq 20$ copies $/ 15 \mu \mathrm{L}$ for $b l a_{\mathrm{NDM}}, b l a_{\mathrm{KPC}}, b l a_{\mathrm{IMP}}$, $b l a_{\mathrm{GES}}$, and $b l a_{\mathrm{OXA}-48}$, and $\geq 10$ copies $/ 15 \mu \mathrm{L}$ for $b l a_{\mathrm{VIM}}$ (Supplementary Table S1). The multiplex assay detected each target gene of the reference or clinical strains without cross reactivity (Table 2). Finally, the assay detected two distinct carbapenemase genes (NDM and OXA-48-like carbapenemase) without false-positive results (Table 3). The assay did not show a false-positive result for the 66 CIM-negative isolates at all.

Set 1
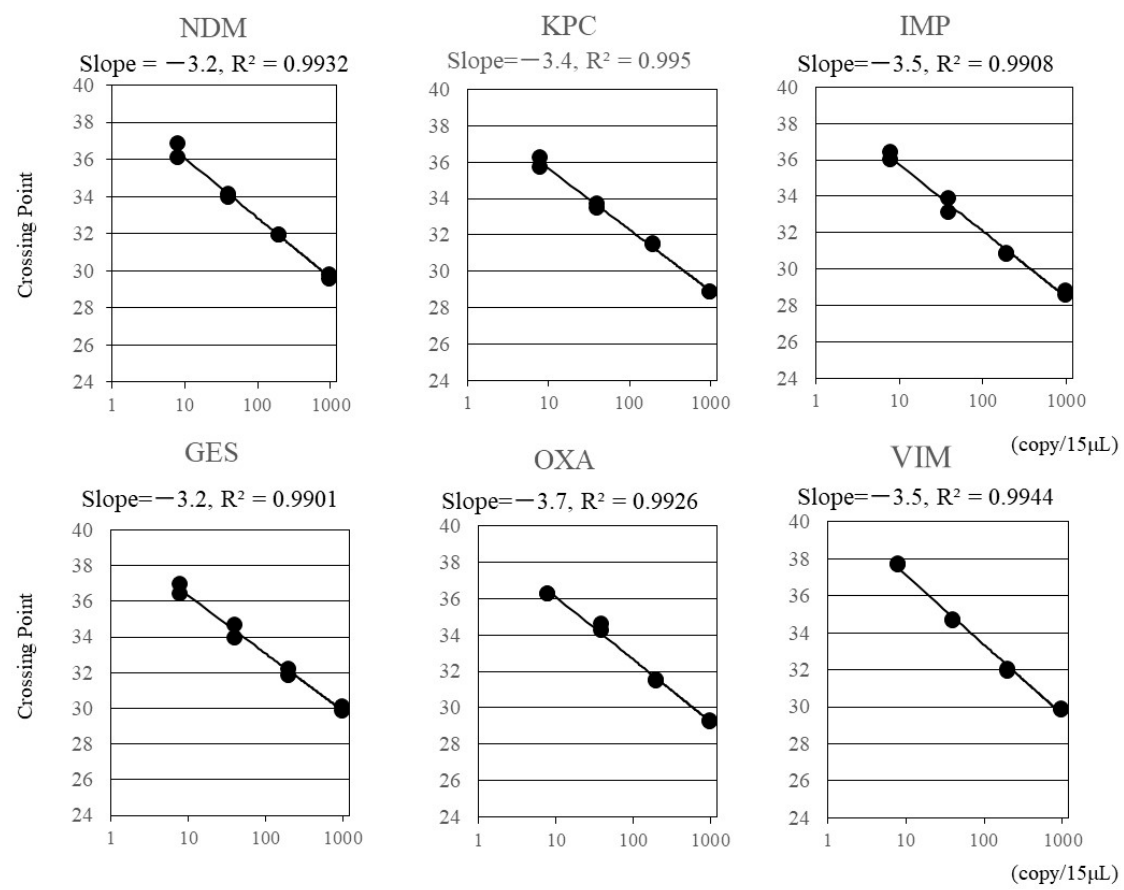

Figure 1. Standard curves for the four-fold serial dilutions of the DNA standards. 
Table 2. Multiplex quantitative real-time PCR assay for six Enterobacteriaceae isolates harboring distinct carbapenemases.

\begin{tabular}{|c|c|c|c|c|c|c|c|}
\hline \multirow{2}{*}{ PCR Set } & \multirow{2}{*}{$\begin{array}{c}\text { Carbapenemase } \\
\text { Type }\end{array}$} & \multicolumn{6}{|c|}{ Genotypes of the Tested Isolates } \\
\hline & & $b l a_{\mathrm{NDM}-5}$ & $b l a_{\mathrm{KPC}-2}$ & $b l a_{\mathrm{IMP}-6}$ & $b l a_{\mathrm{GES}-24}$ & $b l a_{\mathrm{OXA}-232}$ & $b l a_{\mathrm{VIM}-1}$ \\
\hline \multirow{3}{*}{1} & NDM & $19.52 / 19.36$ & n.d. & n.d. & n.d. & n.d. & n.d. \\
\hline & KPC & n.d. & $18.33 / 18.46$ & n.d. & n.d. & n.d. & n.d. \\
\hline & IMP & n.d. & n.d. & $15.93 / 15.85$ & n.d. & n.d. & n.d. \\
\hline \multirow{3}{*}{2} & GES & n.d. & n.d. & n.d. & $16.13 / 16.16$ & n.d. & n.d. \\
\hline & OXA & n.d. & n.d. & n.d. & n.d. & $22.11 / 22 / 15$ & n.d. \\
\hline & VIM & n.d. & n.d. & n.d. & n.d. & n.d. & $17.67 / 17.62$ \\
\hline
\end{tabular}

Target genes for PCR set 1 are $b l a_{\mathrm{NDM}}, b l a_{\mathrm{KPC}}$, and $b l a_{\mathrm{IMP}}$, and target genes for set 2 are $b l a_{\mathrm{GES}}, b l a_{\mathrm{OXA}}$, and $b l a_{\mathrm{VIM}}$. Shown are crossing points (duplicate). n.d., not detected.

Table 3. Multiplex quantitative real-time PCR assay for six Enterobacteriaceae clinical isolates carrying both NDM andOXA-48 like genes.

\begin{tabular}{|c|c|c|c|c|c|c|c|}
\hline \multirow[b]{2}{*}{ PCR Set } & \multirow[b]{2}{*}{$\begin{array}{c}\text { Carbapenemase } \\
\text { Type }\end{array}$} & \multicolumn{6}{|c|}{ Genotypes of the Tested Isolates } \\
\hline & & $\begin{array}{c}\text { Isolate } 1 \\
\text { bla }_{\mathrm{NDM}-1} \\
+ \text { bla }_{\mathrm{OXA232}}\end{array}$ & $\begin{array}{c}\text { Isolate } 2 \\
\text { bla }_{\mathrm{NDM}-1} \\
+ \text { bla }_{\mathrm{OXA232}}\end{array}$ & $\begin{array}{c}\text { Isolate } 3 \\
\text { bla } a_{\mathrm{NDM}-1} \\
+b l a_{\mathrm{OXA} 232}\end{array}$ & $\begin{array}{c}\text { Isolate } 4 \\
\text { bla }_{\mathrm{NDM}-1} \\
+ \text { bla }_{\mathrm{OXA181}}\end{array}$ & $\begin{array}{c}\text { Isolate } 5 \\
\text { bla }_{\mathrm{NDM}-1} \\
+ \text { bla }_{\mathrm{OXA} 232} \text { or } 181\end{array}$ & $\begin{array}{c}\text { Isolate } 6 \\
\text { bla }_{\mathrm{NDM}-1} \\
+ \text { bla } a_{\mathrm{OXA} 232} \text { or } 181\end{array}$ \\
\hline \multirow{3}{*}{1} & NDM & $26.63 / 26.63$ & $25.95 / 25.87$ & $26.21 / 26.16$ & $17.78 / 17.76$ & $27.07 / 27.1$ & $25.44 / 25.54$ \\
\hline & KPC & n.d. & n.d. & n.d. & n.d. & n.d. & n.d. \\
\hline & IMP & n.d. & n.d. & n.d. & n.d. & n.d. & n.d. \\
\hline \multirow{3}{*}{2} & GES & n.d. & n.d. & n.d. & n.d. & n.d. & n.d. \\
\hline & OXA & $27.63 / 27.85$ & $26.95 / 26.94$ & $27.34 / 27.31$ & $25.95 / 25.72$ & $29.55 / 29.56$ & $30.42 / 30.2$ \\
\hline & VIM & n.d. & n.d. & n.d. & n.d. & n.d. & n.d. \\
\hline
\end{tabular}

Shown are threshold cycles (duplicate). n.d., not detected. All the tested isolates were confirmed to harbor both $b l a_{\mathrm{NDM}}$ and $b l a_{\mathrm{OXA}}$, but not other types such as $b l a_{\mathrm{KPC}}, b l a_{\mathrm{IMP}}, b l a_{\mathrm{GES}}$, and $b l a_{\mathrm{VIM}}$, by a previously reported method [11].

Four-fold serial dilutions of positive controls (LightMix ${ }^{\circledR}$ Modular series, Roche Diagnostics K. K., Tokyo, Japan; 8, 40, 200, 1000 copies $/ 15 \mu \mathrm{L}$ ) were used as standard solutions. A line indicates the linear detection range. Correlation coefficients were greater than 0.99 for all genes.

\section{Discussion}

In this study, we demonstrated a potential utility of the multiplex quantitative realtime PCR assay for six major carbapenemase genes using the clinically available COBAS ${ }^{\circledR}$ z480 equipment. The major advantages of the assay are high sensitivity and short procedure duration $(60 \mathrm{~min})$. In addition, the use of UNG and internal control improves assay reliability by preventing carry-over contamination [12] and allowing visualization of amplification products. The wide availability of the equipment at medical facilities may also be beneficial for our assay. A recent study has also described a multiplex PCR assay using LightCycler ${ }^{\circledR} 480$ II (Roche Diagnostics KK, Tokyo, Japan) for the detection of carbapenemase genes [13]. However, the device is for research use only and is not clinically available. Lastly, the cost of our assay is approximately half of that for an existing cassette-type multiplex RT-PCR assay, such as the Xpert CARBA-R assay (approximately 3250 JPY versus 6000 JPY per run, respectively) [14]. Collectively, our method has several strengths compared to the previous methods [15-18].

A potential disadvantage of our assay is that it requires two sets-per-unit to differentiate between six carbapenemase genes; this can be technically complex. We have included $b l a_{\mathrm{GES}}$ in the assay as one of the carbapenemases, although the majority of those may be classified into class A extended-spectrum beta-lactamases. Our aim of developing this assay was to widely screen for $\mathrm{CPE}$, and thus, we incorporated $b l a_{\mathrm{GES}}$ into the primer sets. In fact, many previous studies dealt with bla $a_{\text {GES }}$ as carbapenemase [19-22]. Additionally, an insufficient number of isolates were tested to estimate sensitivity and specificity of the assay, especially below the detection limit. We have no solid explanation for the reason of difference in the detection limit between bla $_{\mathrm{VIM}}$ and other variants. In comparison with 
other countries, the detection rates of CPE isolates in clinical situations are infrequent in Japan. It is, thus, hardly possible to increase the isolates to be tested for the study, and we intend to publish the present data as a preliminary study. Therefore, further investigations should be performed before clinical use. Furthermore, the utility of the assay to directly apply clinical specimen should also be examined.

The early detection of CPE can help in implementing effective countermeasures at an appropriate time to initiate early treatment interventions. The increasing global dissemination of CPE necessitates the preparation of a range of mobile carbapenemase genes. The plasmids harboring carbapenemase genes can be transmitted easily among patients. Our method using the clinically available laboratory equipment can search for genetically diverse CPE isolates with a high accuracy. We believe that our assay would be significantly useful in clinical laboratories.

Supplementary Materials: The following are available online at https:/ / www.mdpi.com/2076-081 7/10/3/276/s1, Table S1: Reproducibility of the multiplex quantitative real time PCR assay using DNA standards.

Author Contributions: Study concept and data extraction: N.Y., M.K. and M.D. Drafting of the manuscript: H.H. Critical revision: S.H., I.N., Y.A. and K.T. All authors have read and agreed to the published version of the manuscript.

Funding: This research received no external funding.

Institutional Review Board Statement: Not applicable.

Informed Consent Statement: The need for informed consent was waived because the study used only isolated pathogens and an individual's information was anonymized.

Data Availability Statement: The data presented in this study are available on request from the corresponding author. The data are not publicly available because they are not opened.

Conflicts of Interest: The authors declare that they have no competing interest.

\section{References}

1. Logan, L.K.; Weinstein, R.A. The epidemiology of Carbapenem-resistant enterobacteriaceae: The impact and evolution of a global menace. J. Infect. Dis. 2017, 215, S28-S36. [CrossRef]

2. Köck, R.; Daniels-Haardt, I.; Becker, K.; Mellmann, A.; Friedrich, A.W.; Mevius, D.; Schwarz, S.; Jurke, A. Carbapenem-resistant Enterobacteriaceae in wildlife, food-producing, and companion animals: A systematic review. Clin. Microbiol. Infect. 2018, 24, 1241-1250. [CrossRef]

3. Yamamoto, N.; Asada, R.; Kawahara, R.; Hagiya, H.; Akeda, Y.; Shanmugakani, R.K.; Yoshidaab, H.; Yukawaa, S.; Yamamotoe, K.; Takayamac, Y.; et al. Prevalence of, and risk factors for, carriage of carbapenem-resistant Enterobacteriaceae among hospitalized patients in Japan. J. Hosp. Infect. 2017, 97, 212-217. [CrossRef] [PubMed]

4. Hagiya, H.; Yamamoto, N.; Kawahara, R.; Akeda, Y.; Shanmugakani, R.K.; Ueda, A.; Nishic, I.; Asadad, R.; Yoshidaa, H.; Tomonoa, K. Risk factors for fecal carriage of IMP-6-producing Enterobacteriaceae at a long-term care hospital in Japan: A follow-up report from the northern Osaka multicentre study group. J. Infect. Chemother. 2018, 24, 769-772. [CrossRef]

5. Iovleva, A.; Doi, Y. Carbapenem-Resistant Enterobacteriaceae. Clin. Lab. Med. 2017, 37, 303-315. [CrossRef] [PubMed]

6. Miller, S.; Humphries, R.M. Clinical laboratory detection of carbapenem-resistant and carbapenemase-producing Enterobacteriaceae. Expert Rev. Anti Infect. Ther. 2016, 14, 705-717. [CrossRef] [PubMed]

7. Shanmugakani, R.K.; Akeda, Y.; Yamamoto, N.; Sakamoto, N.; Hagiya, H.; Yoshida, H.; Takeuchi, D.; Sugawara, Y.; Kodera, T.; Kawase, M.; et al. PCR-dipstick chromatography for differential detection of carbapenemase genes directly in stool specimens. Antimicrob. Agents Chemother. 2017, 61. [CrossRef] [PubMed]

8. Greissl, C.; Saleh, A.; Hamprecht, A. Rapid detection of OXA-48-like, KPC, NDM, and VIM carbapenemases in Enterobacterales by a new multiplex immunochromatographic test. Eur. J. Clin. Microbiol. Infect. Dis. 2019, 38, 331-335. [CrossRef]

9. Glupczynski, Y.; Jousset, A.; Evrard, S.; Bonnin, R.A.; Huang, T.D.; Dortet, L.; Bogaerts, P.; Naas, T. Prospective evaluation of the OKN K-SeT assay, a new multiplex immunochromatographic test for the rapid detection of OXA-48-like, KPC and NDM carbapenemases. J. Antimicrob. Chemother. 2017, 72, 1955-1960. [CrossRef]

10. Wareham, D.W.; Momin, M.H.F.A. Rapid detection of carbapenemases in enterobacteriaceae: Evaluation of the resist-3 O.K.N (OXA-48, KPC, NDM) lateral flow multiplexed assay. J. Clin. Microbiol. 2017, 55, 1223-1225. [CrossRef] [PubMed]

11. Shanmugakani, R.K.; Akeda, Y.; Sugawara, Y.; Laolerd, W.; Chaihongsa, N.; Sirichot, S.; Yamamoto, N.; Hagiya, H.; Morii, D.; Fujiya, Y.; et al. PCR-dipstick-oriented surveillance and characterization of mcr-1- and carbapenemase-carrying Enterobacteriaceae in a Thai hospital. Front. Microbiol. 2019, 10, 149. [CrossRef] 
12. Longo, M.S.; Berninger, J.H. Use of Uracil DNA Glycosylase to Control Carry-Over Contamination in Polymerase Chain Reactions. Gene 1990, 93, 125-128. [CrossRef]

13. Oviaño, M.; Torres, I.; González, M.; Bou, G. Evaluation of a novel procedure for rapid detection of carbapenemase-producing Enterobacteriaceae (CPE) using the LightMix ${ }^{\circledR}$ modular carbapenemase kits. J. Antimicrob. Chemother. 2016, 71, 3420-3423. [CrossRef]

14. Dortet, L.; Fusaro, M.; Naasa, T. Improvement of the Xpert carba-R kit for the detection of Carbapenemase-Producing Enterobacteriaceae. Antimicrob. Agents Chemother. 2016, 60, 3832-3837. [CrossRef] [PubMed]

15. Monteiro, J.; Widen, R.H.; Pignatari, A.C.; Kubasek, C.; Silbert, S. Rapid detection of carbapenemase genes by multiplex real-time PCR. J. Antimicrob. Chemother. 2012, 67, 906-909. [CrossRef] [PubMed]

16. van der Zee, A.; Roorda, L.; Bosman, G.; Fluit, A.C.; Hermans, M.; Smits, P.H.; van der Zanden, A.G.M.; Witt, R.; van Coppenraet, L.E.S.B.; Stuart, J.C.; et al. Multi-centre evaluation of real-time multiplex PCR for detection of carbapenemase genes OXA-48, VIM, IMP, NDM and KPC. BMC Infect. Dis. 2014, 14, 27. [CrossRef]

17. Smiljanic, M.; Kaase, M.; Ahmad-Nejad, P.; Ghebremedhin, B. Comparison of in-house and commercial real time-PCR based carbapenemase gene detection methods in Enterobacteriaceae and non-fermenting gram-negative bacterial isolates. Ann. Clin. Microbiol. Antimicrob. 2017, 16, 48. [CrossRef] [PubMed]

18. Teo, J.W.; La, M.V.; Lin, R.T. Development and evaluation of a multiplex real-time PCR for the detection of IMP, VIM, and OXA-23 carbapenemase gene families on the BD MAX open system. Diagn. Microbiol. Infect. Dis. 2016, 86, 358-361. [CrossRef]

19. Oho, M.; Funashima, Y.; Nagasawa, Z.; Miyamoto, H.; Sueoka, E. Rapid detection method of carbapenemase-producing Enterobacteriaceae by MALDI-TOF MS with imipenem/cilastatin (KB) disc and zinc sulfate solution. J. Infect. Chemother. 2021, 27, 205-210. [CrossRef]

20. Manageiro, V.; Romão, R.; Moura, I.B.; Sampaio, D.A.; Vieira, L.; Ferreira, E.; Network EuSCAPE-Portugal; Caniça, M. Molecular Epidemiology and Risk Factors of Carbapenemase-Producing Enterobacteriaceae Isolates in Portuguese Hospitals: Results from European Survey on Carbapenemase-Producing Enterobacteriaceae (EuSCAPE). Front. Microbiol. 2018, 9, 2834. [CrossRef]

21. Kim, S.H.; Kim, G.R.; Jeong, J.; Kim, S.; Shin, J.H. Prevalence and Characteristics of Carbapenemase-Producing Enterobacteriaceae in Three Tertiary-Care Korean University Hospitals between 2017 and 2018. Jpn. J. Infect. Dis. 2020, 73, 431-436. [CrossRef] [PubMed]

22. Meunier, D.; Woodford, N.; Hopkins, K.L. Evaluation of the AusDiagnostics MT CRE EU assay for the detection of carbapenemase genes and transferable colistin resistance determinants mcr-1/-2 in MDR Gram-negative bacteria. J. Antimicrob. Chemother. 2018, 73, 3355-3358. [CrossRef] [PubMed] 